DOI https://doi.org/10.18551/rjoas.2020-11.17

\title{
GROUNDWATER QUALITY MONITORING IN MAGELANG CITY DURING THE COVID-19 PANDEMIC
}

\author{
Aji Muhammad Tri ${ }^{*}$, Jailani Abdul Qadir \\ Study Program of Aquaculture, Faculty of Agriculture, University of Tidar, \\ Magelang, Indonesia \\ *E-mail: triaji@untidar.ac.id
}

\begin{abstract}
This study aimed to determine the impact of detergents during the Covid-19 pandemic on the quality of groundwater in Magelang City. The determination of the research sites for the needs of water sampling was carried out using a purposive sampling method. Water quality parameters analysis can be carried out in situ and ex-situ and will later be compared with the water quality standards following the Government Regulation or Peraturan Pemerintah (PP) No.82 of 2001 and the Ministry of Health Regulation or Peraturan Menteri Kesehatan (Permenkes) No.32 of 2017. The results showed that the physical parameters were still in good condition with an average temperature of $26.1^{\circ} \mathrm{C}$, while the TSS (Total Suspended Solid) and TDS (Total Dissolved Solid) values were $3.7 \mathrm{mg} / \mathrm{L}$ and $227.95 \mathrm{mg} / \mathrm{L}$. Meanwhile, the $\mathrm{pH}$ showed a fairly fluctuating value, and at some stations, the groundwater was acidic with a value below 7 . Nitrate values at research stations 1,6,7 and 9 exceeded the established threshold of $10 \mathrm{mg} / \mathrm{L}$. Later on, the BOD's (Biological Oxygen Demand) value should more than $2 \mathrm{mg} / \mathrm{L}$ to enter class 1 or safe and hygienic groundwater and the COD's (Chemical Oxygen Demand) value was $10 \mathrm{mg} / \mathrm{L}$ at all station research, exceeding the maximum requirement. Therefore, it is categorized as heavy pollution, and the DO (Dissolved Oxygen) tends to vary from $2.51 \mathrm{mg} / \mathrm{l}$ to $7.24 \mathrm{mg} / \mathrm{l}$. According to Permenkes No.32 of 2017, the total coliform value exceeding the water quality standard for sanitation hygiene purposes was $50 \mathrm{MPN} / 100 \mathrm{ml}$. The organoleptic test results showed the same characteristics, namely clear, odorless and tasteless, except for groundwater contaminated by rat carcasses. The detergent content in groundwater is still in good and safe condition because it is $<0.002 \mathrm{mg} / \mathrm{l}$. It is intended that the existing aquifer can reduce the detergent content within the groundwater. The quality of groundwater in Magelang City can be used for drinking water, but still must go through a cooking process first.
\end{abstract}

\section{KEY WORDS}

Groundwater quality, Magelang City, COVID-19 pandemic.

WHO has declared Corona Virus Disease 2019 (COVID-19) a pandemic. The COVID19 has spread across regions and countries. Besides, the number of cases and the deaths are now rising every day. This situation is increasingly having an impact on political, economic, social, cultural, defense and security aspects, as well as the welfare of the Indonesian, so a comprehensive strategy and efforts are needed to accelerate the handling of COVID-19. During a pandemic like this, the community is obliged to implement a more clean and healthy lifestyle. It is as recommended by the government in the Decree of Ministry of Health or Keputusan Menteri Kesehatan (KEPMENKES) No.HK.01.07/2020. Such a clean and healthy lifestyle does not escape the use of chemicals (detergents or soap) as a cleanser and water as a rinse.

The people of Magelang City almost entirely use groundwater as the primary raw material for drinking water, cooking activities, and industrial activities. Water for human consumption must be free of microorganisms and chemical substances in large enough concentrations because it can cause environmental imbalances and diseases (Aremu et al., 2011; Shivaraju, 2012). It should be noted that an improper water purification process will lead to the surfactants in clean water. It is because its physicochemical properties (high water solubility and poor degradability), allowing penetrate all-natural and human-made 
filtration steps, will potentially cause problems in the provision of drinking water (Norfazrin et al., 2012 in Hanan S., et al., 2014).

Environmental studies show that the use of detergents is proliferating in developing countries and rural communities (Feisthauer et al., 2004). Detergents play a significant role in increasing pollution originating from settlements in the form of household detergents, agricultural runoff in the form of herbicides and insecticides, and from specific industries (Vinod et al., 2012). About $90-97 \%$ of detergents can be degraded by bacteria and broken down in small amounts under anaerobic conditions (Yangxin et al., 2008).

This study aimed to determine the current conditions regarding the quality of groundwater in Magelang City during the COVID-19 pandemic.

\section{METHODS OF RESEARCH}

This study was conducted on several districts, such as North Magelang, Central Magelang, and South Magelang districts with 10 sampling stations with 2 replications. It was don in July 2020. The determination of the research site for the needs of water sampling was carried out using a purposive sampling method. Parameter analysis can be done in situ and ex-situ. The parameters analyzed were temperature, TSS, TDS, pH, Nitrate, BOD, COD, DO, detergent, Total Colliform, and organoleptic test of groundwater. Furthermore, the data was analyzed descriptively and then compared with PP No. 82 of 2001 and Permenkes No.32 of 2017.

\section{RESULTS AND DISCUSSION}

Magelang City, with an area of $18,463,049 \mathrm{~m}^{2}$, has the availability of groundwater with calculations using a hydrogeological map of 8.04 million $\mathrm{m}^{3} /$ year (Pratiknyo, 2017). Magelang City is known to have a lithological composition of constituent rocks, namely an old volcanic rock unit that consists of lava and tuff. Based on the type of lithology, the hydraulic conductivity values ranges from 10-3 to $10 \mathrm{~m} /$ day (Domenico \& Schwartz, 1990). The analysis results of the groundwater quality after sampling at 10 observation stations with 2 repetitions showed varied results.

Physical Parameters. The measurement value of the average groundwater temperature was conducted at 10 different stations in 3 districts, namely North, Central, and South Magelang.

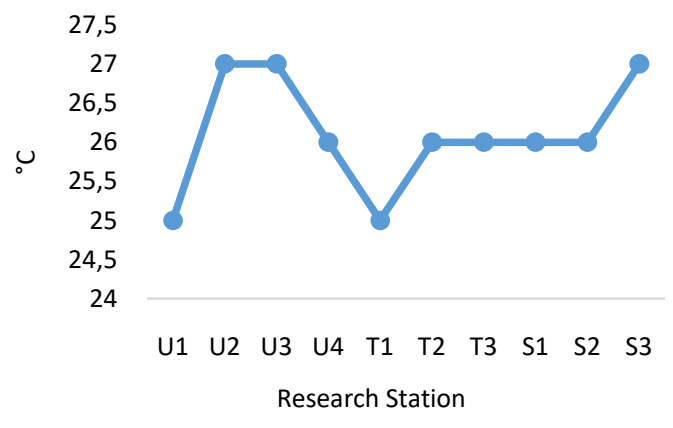

Figure 1 - Average value of groundwater temperature in Magelang City

Physical parameters of groundwater temperature showed normal results in 2 repetitions with an average of $26^{\circ} \mathrm{C}$. The temperature value at the research station did not experience high fluctuation because the weather at the time of sampling was quite sunny. The sampling time was between $06.00-09.00$ p.m so that the extended sun exposure did not affect an increase in water temperature. 


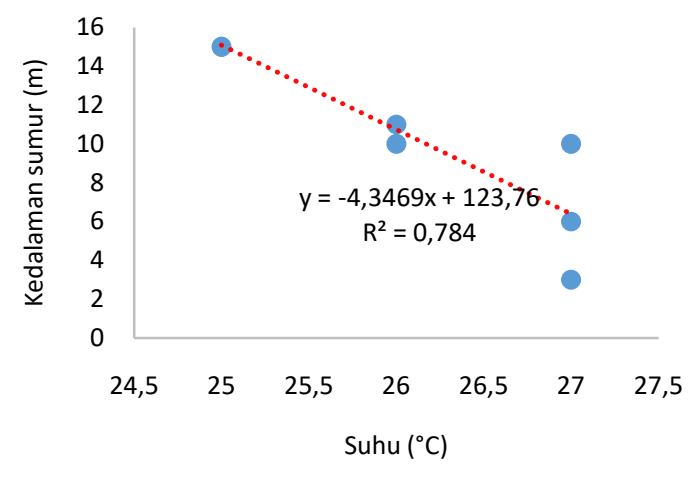

Figure 2 - The relationship between depth and temperature

From the picture above, the $\mathrm{R}^{2}$ value was 0.784 , revealing that the depth of the soil source affected the value of water temperature. From the results of the location survey per research station, it was found that the level of groundwater in Magelang City ranged from 3$10 \mathrm{~m}$.

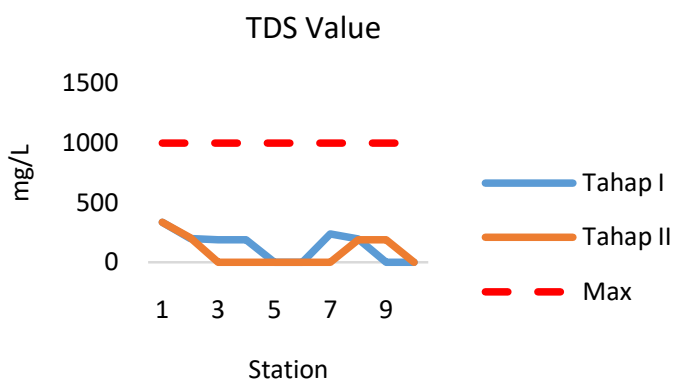

Figure 3 - TDS Measurement Value in Magelang City

Based on the TDS calculation results at 10 research stations, the TDS levels in the sample ranged from $190 \mathrm{mg} / \mathrm{L}$ to $337 \mathrm{mg} / \mathrm{L}$. If compared to the class I clean water quality standard, qualified for household needs with the maximum allowable TDS value of 1000 $\mathrm{mg} / \mathrm{L}$, the TDS level at research stations was still in the normal range. The condition of the station location, generally close to the sewer water, affected the TDS content. Domestic activities such as washing also affected the TDS content in groundwater. It agrees Jatmiko's (2007) opinion that the location of the ditch by $\leq 25 \mathrm{~m}$ away will affect the condition of well water, especially for the TDS parameter. This is because sewage water contains a lot of organic, inorganic, sediment and other dissolved solid waste materials.

TSS Value

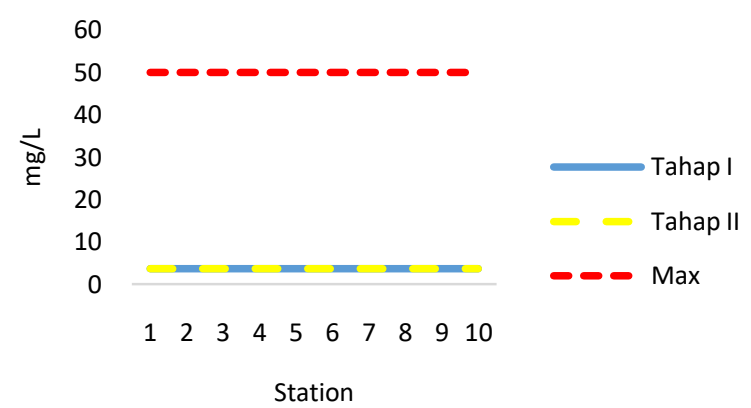

Figure 4 - TSS Measurement Value in Magelang City 
The TSS content analysis also had excellent results below the predetermined threshold value when compared to the two regulations that have been set by the government, namely PP No. 82 Year 2001 and Permenkes No.32 of 2017. From 2 replications, all research locations showed excellent results, namely $<3.72161 \mathrm{mg} / \mathrm{l}$.

Chemical Parameters. The degree of acidity or $\mathrm{pH}$ is a measure to determine the acidic and alkaline properties of water. $\mathrm{pH}$ changes in water significantly affect the physical, chemical, and biological processes of the organisms that live and exist within. The $\mathrm{pH}$ value of water is used to express the acidity (hydrogen ion concentration) conditions of wastewater (Ningrum, 2018). Figure 5 indicates the results of $\mathrm{pH}$ value measurement at each research station.

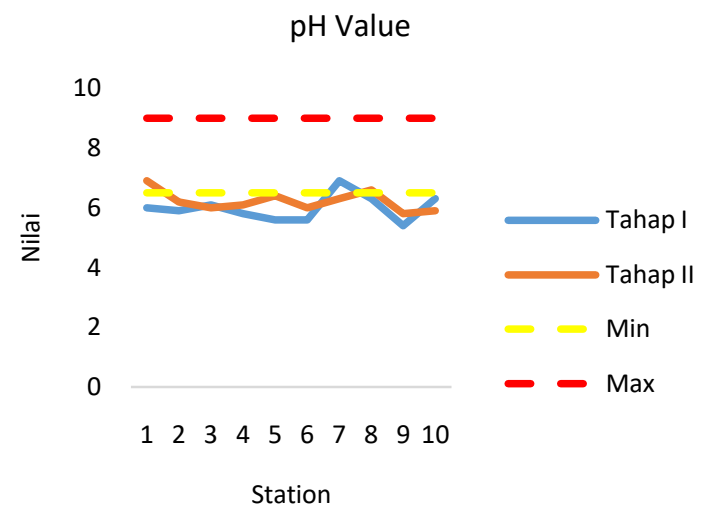

Figure $5-\mathrm{pH}$ value at each research station

The changes in $\mathrm{pH}$ value will have a significant effect on the physical, chemical and biological processes. The $\mathrm{pH}$ analysis results from the 10 research locations ranged from 5.4 to 6.9. The $\mathrm{pH}$ value showed the high and low level of hydrogen ions in water, where a $\mathrm{pH}$ of less than 6.5 or above 9 will cause chemical compounds in the human body to turn into toxins that can interfere with health (Putra, 2019).

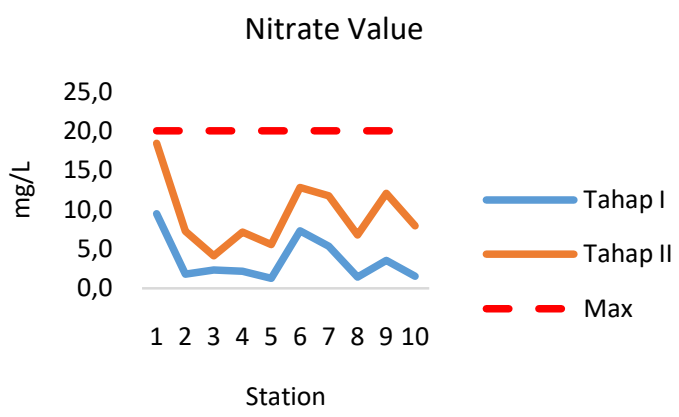

Figure 6 - Nitrate Value at research station

The content of nitrate levels in groundwater increased quite drastically in the second repetition, while the 1st repetition the nitrate content in the groundwater was quite good and none exceeded the threshold for sanitation hygiene needs, which was below $10 \mathrm{mg} / \mathrm{l}$. However, in repetition 2, there was a relatively high increase in several sampling locations, one of which was at the North Magelang 1 (U1) of $18.402 \mathrm{mg} / \mathrm{l}$. This high concentration of nitrate can be triggered by the relatively high discharge of domestic waste, considering that the location is a densely populated environment. Also, the location of the well is close to the septic tank so that it will undoubtedly produce much organic matter and seep into groundwater. Nitrate (NO 3-) is a ubiquitous environmental pollutant that not only occurs 
naturally but also is released by human activities. These activities include the production and use of fertilizers, combustion of fossil fuels (resulting in atmospheric deposition, henceforth AD), leakage and disposal of industrial and domestic sewage systems, and the alteration of natural vegetation with nitrogen-fixing (N) plants (Gutiérrez et al., 2018; Ward et al., 2018).

Nitrogen compounds (nitrite, nitrate and ammonia) in waters naturally come from the metabolism of aquatic organisms and the decomposition of organic materials by bacteria (Indrayani et. al., 2015). In addition, nitrites and nitrates in nature can be produced naturally or from human activities. The natural source of nitrite and nitrate is the nitrogen cycle, while the source of human activities comes from the use of nitrogen fertilizers, industrial waste, and human organic waste. The formation of nitrites and nitrates in the nitrogen cycle occurs through the process of nitrogen fixation by Rhizobium bacteria, nitrification and nitrification by denitrification Pseudomonas bacteria. Nitrification involves two processes, namely nitritation by Nitrosomonas bacteria and nitratation by Nitrobacter bacteria. In anaerobic conditions, nitrate is a relatively stable form of nitrogen but can be reduced to nitrite through the nitratation process (Rosca et. Al., 2009).

The content of BOD is the need for dissolved oxygen levels used by microorganisms to decompose organic matter in waters (Ningrum, et. al., 2018). The BOD value does not indicate the actual amount of organic matter but only measures the relative amount of oxygen required to oxidize the waste material. If the oxygen consumption is high, the smaller the remaining dissolved oxygen, the higher the waste material content that requires oxygen (Rachmawati, et. Al.2013).

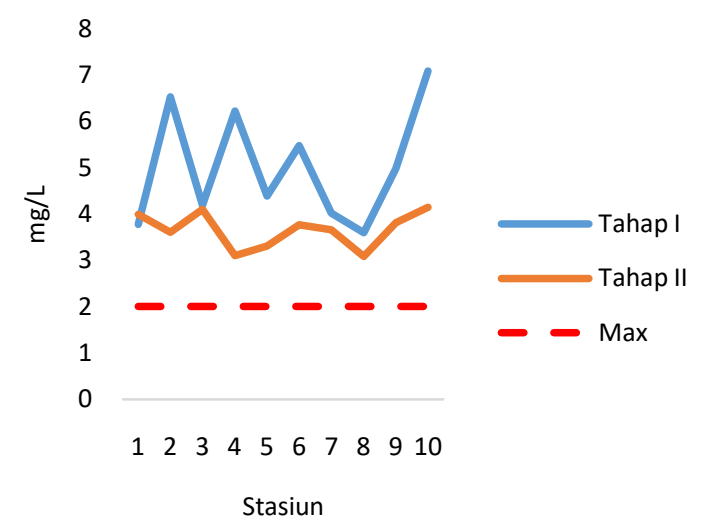

Figure 7 - BOD value of groundwater in Magelang City

The results of BOD measurement value at 10 stations with 2 replications exceeded the threshold set by PP no.82 of 2001 . The maximum limit is $2 \mathrm{mg} / \mathrm{L}$ for class 1 , namely water whose designation can be used for drinking water and/or other designations that require the same water quality as the said use. The high BOD value at the research station is thought to be due to the density of people's houses and septic tanks located close to the well, as well as the seepage of pollutants caused by anthropogenic activities. The picture above also illustrates that the water quality standard for the BOD parameter is in class 3 where the water designated for freshwater fish cultivation, livestock, water to irrigate crops, and/or other designations that require the same water with these uses.

$\mathrm{COD}$ value is the amount of oxygen $\left(\mathrm{mg} \mathrm{O}_{2}\right)$ needed to oxidize organic substances in 1 litre of water, where oxidizing organic substances are in 1 litre of water (Rachmawati, 2003). The results of the research in Figure 8 showed that the COD content at 10 stations with 2 replications obtained a value that exceeds the threshold in government regulation no.82 of 2001, namely $10 \mathrm{mg} / \mathrm{L}$. Water quality standard with a concentration of COD $<5 \mathrm{mg} / \mathrm{L}$ is included in very light pollution, COD 6-9 mg/L in light pollution, COD 10-15 mg/L in moderate pollution, and COD> $16 \mathrm{mg} / \mathrm{L}$ in heavy pollution. Based on the comparison of the quality 
standard figures, it can be concluded that all research stations in Magelang City have experienced a water pollution level with a heavy pollution category.

COD Value

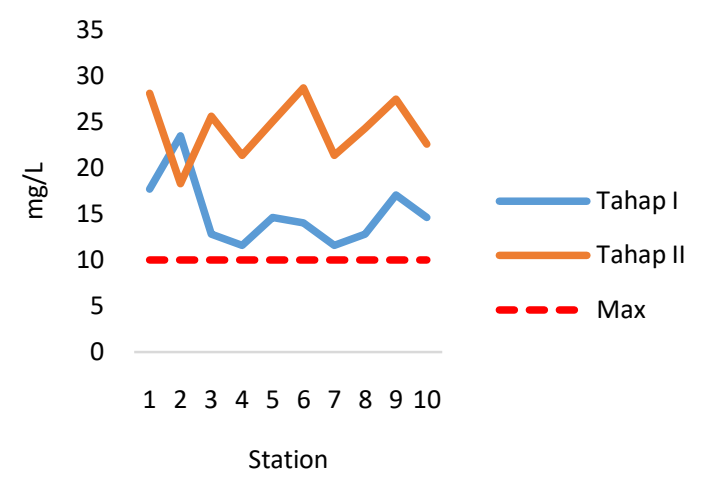

Figure $8-C O D$ value of groundwater in Magelang City

The DO content in groundwater in Magelang City has varied results, ranging from 2.16 - $7.40 \mathrm{mg} / \mathrm{l}$ and had an average dissolved oxygen content of $4.31 \mathrm{mg} / \mathrm{l}$. The lowest dissolved oxygen content value was in the S3 location in the southern Magelang sub-district. The DO content value of $2.16 \mathrm{mg} / \mathrm{l}$ was still in the appropriate category, considering that the water sample come from well water with a depth of $\pm 5 \mathrm{~m}$, resulting in very minimal exposure to direct oxygen diffusion from the air. Although it is very minimal exposure to direct oxygen diffusion from the air, the biological oxidation process continues at that location by looking at the BOD values of 7.09 and $4.15 \mathrm{mg} / \mathrm{l}$ at the $\mathrm{S} 3$ location.

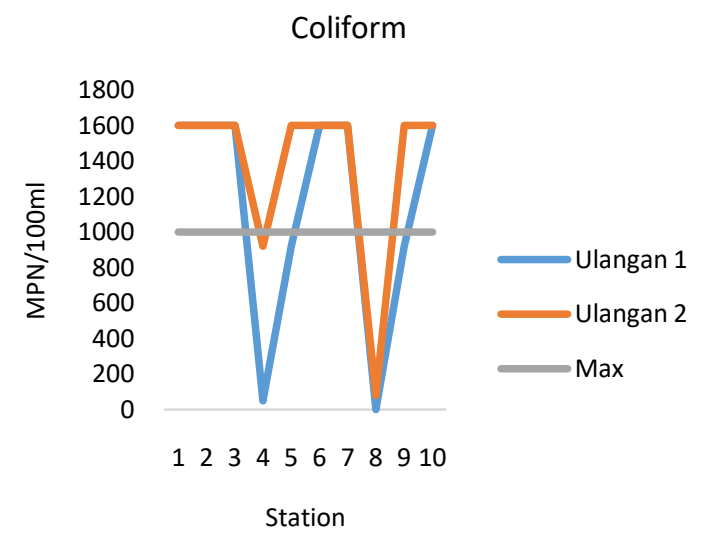

Figure 9 - The total value of groundwater Coliform in Magelang City

The highest value of dissolved oxygen in water is at location $\mathrm{S} 1 \mathrm{of} 7.40 \mathrm{mg} / \mathrm{l}$. This high value can be caused by a large amount of oxygen diffusion directly from the air into the water, considering that the well at this location is not too deep. The primary source of oxygen in water comes from a diffusion process from free air and the photosynthesis of organisms living in the water. Oxygen is used by aquatic organisms for the respiration process and breaks down organic substances into inorganic substances by microorganisms. Dissolved oxygen in water comes from air diffusion and the results of photosynthesis of chlorophyll organisms that live in waters and are needed by organisms to oxidize nutrients that enter their bodies (Handayani, 2017). Figure 9 below indicates an overview of the results of further chemical parameter analysis. 
Biological Parameters. One of the conditions of groundwater in Magelang City can be seen from the bacteriological parameters of coliform found in groundwater. Of the 10 sampling locations and 2 replications, almost all sampling locations had total coliform values that exceeded the water quality standard for sanitation hygiene purposes following Permenkes No.32 of 2017 by 50 MPN/100ml while the average analysis results showed that all exceed the quality standards required by Permenkes No.32 of 2017. The high content of Coliform can come from the discharge of domestic waste that is too high. It is seen from the close distance between residents' houses and the poor layout of the latrines that are too close to the well. The research results (Khomariyatika and Eram, 2011) showed that microbiological contamination was due to the location of the bucket and the distance of the latrine. Environmental conditions around it will significantly influence the existence of microbes. The distance of latrines and other sources of pollutants close to dug wells will increase contamination and the bucket put in an unclean place will increase the presence of microbes.

Coliform bacteria contamination is caused by the presence of waste both from domestic waste and industrial waste. Organic waste material derived from industrial waste and household waste was generally in the form of waste that can rot or be degraded by microorganisms. Thus, it can result in the development of microorganisms and pathogenic microbes, which cause various diseases (Widiyanto et al., 2015). However, this groundwater would be very suitable for fishery and agricultural activities when viewed from PP.82 of 2001 which has a threshold of $5000 \mathrm{MPN} / \mathrm{ml}$ for class 2 water quality standards.

Table 1 - Organoleptic Test Results for Groundwater in Magelang City

\begin{tabular}{cccccc}
\hline & & \multicolumn{4}{c}{ Organoleptic Parameter } \\
\cline { 3 - 6 } No. & St & Odor & Replication 2 & Replication 1 & Replication 2 \\
\hline 1 & UI & Odorless & Odorless & Tasteless & Tasteless \\
2 & U2 & Odorless & Smell from rats & Tasteless & Tasteless \\
3 & U3 & Odorless & Odorless & Tasteless & Tasteless \\
4 & U4 & Odorless & Odorless & Tasteless & Tasteless \\
5 & T1 & Odorless & Odorless & Tasteless & Tasteless \\
6 & T2 & Odorless & Odorless & Tasteless & Tasteless \\
7 & T3 & Odorless & Odorless & Tasteless & Tasteless \\
8 & S1 & Odorless & Odorless & Tasteless & Tasteless \\
9 & S2 & Odorless & Odorless & Tasteless & Tasteless \\
10 & S3 & Slightly Earthy & Slightly Earthy & Tasteless & Tasteless \\
\hline
\end{tabular}

Organoleptic Test. Based on the data from the organoleptic test results, the groundwater in Magelang City has almost the same characteristics. According to the smell of water from 10 research locations, there are two different sampling locations, namely at station U2, having a relatively strong odour due to rats in the well. Furthermore, at station S3, there is a slight smell of soil in the water samples. This can be caused by the weathering of soil and rock that occurs in the well. Rotten water contains organic matter decomposed by water microorganisms. This odor is likely due to bacterial activity. Bacteria use iron or sulfur in their life cycle and emit hydrogen and sulfide gases which are the cause of odor (Sari and Huljana, 2019).

The taste of water from all research was the same, namely tasteless. It showed that groundwater in Magelang City, based on Permenkes RI No. 32 of 2017 concerning water needs for sanitation hygiene in groundwater must be odorless and tasteless. Groundwater chemically contains small amounts of natural gases, minerals and organic matter. Odors can be an indirect clue to determine water quality. According to (Effendi, 2003), quality and safe water for consumption is water that has an odorless characteristic when it is smelled from far or from close.

The Value of Groundwater Detergent in Magelang City. The measurement results of the detergent content in groundwater in Magelang City, taken from 10 research sites with 2 replications, showed that the results were $<0.002 \mathrm{mg} / \mathrm{l}$. Regarding the maximum standard set by the government based on the Permenkes No. 32 of 2017, the detergent threshold value 
for sanitation hygiene is $0.05 \mathrm{mg} / \mathrm{l}$. All study sites showed the same results. Community's behavior during the covid-19 pandemic to use detergents as anticipation and suggestion of a clean and healthy living program movement did not have a real impact on the quality of groundwater in Magelang City. The low detergent content in the groundwater of Magelang City can be caused by the filtering of these harmful substances in the soil layer. Groundwater pollution takes a long time because the waste does not directly enter the groundwater. Waste disposed of through sewers or septic tanks will flow through gaps or parts that have been damaged and will eventually enter groundwater. The soil layer itself is a filter that can filter out all the substances or waste that enter the soil (Priyana, 1991). Therefore, when it reaches the groundwater carrier layer or aquifer, the detergent content has been increasingly degraded.

The aquifer in Magelang City consists of 2 groups, namely: aquifers with a flow system through inter-grain spaces and local through gaps; and aquifers using fractures, fissures, and spaces between grains. Aquifers with a flow system through the inter-grain and local spaces through the distribution gap are in the central to northern part of Magelang City. It occupies about $75 \%$ of the total area of Magelang City or about $13,845 \mathrm{~km} 2$. Aquifer by means fractures, fissures and spaces between grains; Its distribution is in the southern part of Magelang City with an area of about $25 \%$ of the area of Magelang City, or about $4,615 \mathrm{~km} 2$ (Pratiknyo, 2017).

\section{CONCLUSION}

Physical parameters consisting of temperature, TSS and indicate a good value or following quality standards. Chemical parameters such as nitrate values are still at a safe value for use, while the $\mathrm{pH}, \mathrm{BOD}$, and $\mathrm{DO}$ parameters show values that exceed the class 1 designation threshold. Even the COD parameter for groundwater in Magelang City is included in the criterion of being heavily polluted. The Total Coliform value falls into the excellent category for class 2 designation. The detergent content in groundwater in Megalang City shows a good value $<0.05 \mathrm{mg} / \mathrm{l}$; presumably because the aquifer content can reduce the detergent content.

\section{REFERENCES}

1. Agustira dkk, 2013.Kajian Karakteristik Kimia Air, Fisika Air and Debit Sungai Pada Kawasan Das Padang Akibat Pembuangan Limbah Tapioka.Jurnal Online Argoekoteknologi, Medan.

2. Aremu, M.O., Ozonyia, G.N., Ikokoh, P.P., 2011.Physicochemical properties of well, borehole stream waters in Kubwa, Bwari Area Council, FCT, and Nigeria. Electron. J. Environ. Agric. Food Chem.10 (6), 2296-2304.

3. Domenico, Patrick A.\& Schwartz, Franklin W., 1990, Physical and Chemical Hydrogeology, John Wiley \& Sons, New York, Chicester, Brisbane, Toronto, Singapore.

4. Effendi H.2003.Telaah Kualitas Air bagi Pengelolaan Sumber Daya and Lingkungan Perairan. Cetakan Kelima. Yogyakarta: Kanisus.

5. Feisthauer, N., Sibley, P., Burke, S., Kaushik, N., 2004.A review of the toxicity of detergents and its formulation components on aquatic organisms. Int. J. Ecol. Environ. Sci.28, 223-297.

6. Gutiérrez, M., Biagioni, R.N., Alarcón-Herrera, M.T., Rivas-Lucero, B.A., 2018.An overview of nitrate sources and operating processes in arid and semiarid aquifer systems. Sci. Total Environ.624, 1513-1522.

7. Hanan S.Abd El-Gawad.2014.Aquatic environmental monitoring and removal efficiency of detergents.Science Direct. Water Sience. 28 (2014) 51-64.

8. Handayani, Leni.2017.Pengaruh Kandungan Deterjen Pada Limbah Rumah Tangga Terhadap Kelangsungan Hidup Udang Galah (Macrobracium Rosenbergii).SEBATIK $1410-3737$. 
9. Indrayani, E., Nitimulya, K.H., Hadisusanto, S., and Rustadi, 2015.Analisis Kandungan Nitrogen, Fosfor and Karbon Organik di Danau Sentani Papua.Jurnal Manusia and Lingkungan, 22(2):217-225.

10. Khomariyatika and Eram.2011.Kualitas Bakteriologis Air Sumur Gali.Kemas, 7(1):63-72

11. Mairizki, F.\& Cahyaningsih, C., Groundwater Quality Analysis in the Coastal of Bengkalis City.J.Dyn., 1(2):82-87 (2016).

12. Ningrum, S., Analisis Kualitas Badan Air and Kualitas Air Sumur di Sekitar Pabrik Gula Rejo Agung Baru Kota Madiun.J.Kesehat.Lingkung., 10(1):1-12 (2018).

13. Norfazrin, M.H., Siti, N.N.A., Mohd, T.L., Zuriati, Z., Pauzi, A.M.R.O., 2012.The composition of surfactants in river water and its influence to the amount of surfactants in drinking.World Appl.Sci.J.17 (8), 970-975.

14. Putra, Y.P. and Putri Ade Rahma Yulis.2019.Kajian Kualitas Air Tanah Ditinjau dari Parameter pH, Nilai COD and BOD pada Desa Teluk Nilap Kecamatan Kubu Babussalam Rokan Hilir Provinsi Riau.Jurnal Riset Kimia.Vol.10, No.2, September 2019

15. Peraturan Menteri Kesehatan Republik Indonesia Nomor 32 Tahun 2017.Tentang Standar Baku Mutu Kesehatan Lingkungan and Persyaratan Kesehatan Air Untuk Keperluan Higiene Sanitasi, Kolam Renang, Solus Per Aqua, and Pemandian Umum.

16. Peraturan Pemerintah Nomor 82.Tahun 2001.Tentang Pengelolaan Kualitas Air and Pengendalian Pencemaran Air.

17. Pratiknyo, P.2017. Analisis keberadaan and ketersediaan air tanah berdasarkan Peta hidrogeologi and cekungan air tanah di Kota Magelang.Vol 1, No.2 2017 p.01-08.

18. Priyana, Yuli.1991.Pencemaran Air Tanah Di Perkotaan.Forum Geografi No.09 Tahun V/Desember 1991.

19. Rahmawati, R., Chadijah, S.\& Ilyas, A., 2013.Analisa Penurunan Kadar COD and BOD Limbah Cair Laboratorium Biokimia UIN Makassar Menggunakan Fly Ash (Abu Terbang) Batubara.Al-Kimia, 1(1):64-75.

20. Rosca, V., Duca, M., De Groot, M.T., and Koper, M.T.M., 2009.Nitrogen Cycle Electrocatalysis.Chem.Rev, 109:2209-2244.

21. Sari, Mayang and Huljana, Mifta.2019. Analisis Bau, Warna, TDS, pH, and Salinitas Air Sumur Gali di Tempat Pembuangan Akhir. ALKIMIA: Jurnal IImu Kimia and Terapan.Vol.3 No.12019.

22. Shivaraju, H.P., 2012.Assessment of physico-chemical and bacteriological parameters of drinking water in Mysore City, India.Int.J.Res.Chem.Environ.2 (1), 44-53.

23. Vinod, D., Neha, S., Shalini, S., Archna, S., Aparna, P., 2012.Effect of detergent use on water quality in Rewa City of India.J.Appl.Chem.(IOSRJAC) 1 (4), 28-30.

24. Ward, M., Jones, R., Brender, J., de Kok, T., Weyer, P., Nolan, B., Villanueva, C., van Breda, S., 2018.Drinking Water Nitrate and Human Health:An Updated Review. Int. J. Environ. Res. Public Health 15, 1557. https://doi.org/10.3390/ijerph15071557.

25. Widiyanto, A.F.Saudin Yuniarno, Kuswanto. 2015. Polusi Air Tanah Akibat Limbah Industri and Limbah Rumah Tangga. KEMAS 10 (2) (2015) 246-254.

26. Yangxin, Y., Jin, Z., Bayly, A.E., 2008.Development of surfactants and builders in detergent formulations.Chin.J.Chem.Eng.14 (4), 517-527.

27. Zeffitni, 2012.Agihan Spasial Ekologikal Potensi Air Tanah untuk Kebutuhan Domestik di Cekungan Air Tanah Palu Provinsi Sulawesi Tengah.Jurnal Manusia and Lingkungan, 19(2):105-117. 